\title{
Nutritional Assessment and Physical Activity of the Departments for Nutrition\&Dietetics and Nursing Students at a Foundation University
}

\author{
(i) Ayşe GÜNEŞ BAYIR, iD Duygu GÜÇLÜ
}

Bezmialem Vakıf University Faculty of Health Sciences, Deparment of Nutrition and Dietetics, İstanbul, Turkey

\begin{abstract}
Objective: Nutritional assessment and physical activity habits of nutrition $\&$ dietetics students (experimental group) who took a course of The Principles of Nutrition and nursing students (control group) who did not take this course were compared.

Methods: Students were completed the questionnaire included sociodemographic data, 24-h recall with food consumption and food frequency tests, and physical activity habits. My plate replicates were also used as visual material. Body mass index was calculated by bioelectrical body analyzer. Data were analyzed using the Nutrition Information System and SPSS software programs.

Results: Almost half of students were participated in this study (49.5\%). Intake of total energy and nutrients was similar and poor in both groups. It was found that overweight rate and waist circumference measurement of Nursing students are higher and their physical activity are lower than Nutrition and Dietetics students $(\mathrm{p}<0.001)$.

Conclusion: Along with the emergence of inadequate nutrition of the students of both departments, more nutrition education and healthy menu planning are also required for the students of the department of nutrition and dietetics.
\end{abstract}

Keywords: Eating habits, university students, body mass index, nutrients, physical activity

\section{Introduction}

The World Health Organization (WHO) defines health as having a complete physical, mental and social well-being in an individual (1). The two most important determinants of health are adequate and balanced nutrition and regular physical activity (2).

The University period, which is the transition from adolescence to adulthood, is stressful for many students and is a period in which students experience an increase in inadequate and unbalanced eating habits $(3,4)$. In this period, in order to prevent health problems that may arise in older ages, it is necessary to define the nutritional status of individuals, to determine the reasons and to monitor and evaluate the nutritional status of individuals in order to find solutions. Determination of nutritional status is possible with many methods (2). Most frequently used methods are; patient's anamnesis, anthropometric measurements (waist circumference, height-weight account, etc.), 24-hour food consumption scale, food consumption frequency and recall with scale, diet history, biochemical tests, etc. However, using a combination of several of these methods is realistic to determine the nutritional status. For example, they validate the information obtained when evaluated together with the frequency of food consumption and the 24-hour food consumption and gives information about the food recall with pattern (2). Food 
consumption frequency and consumption of food or groups of nutrients can be determined as daily, weekly or monthly and as quantity when requested.

Regular physical activity prevents the formation of obesity and also of many diseases (5). According to a study conducted in the Faculty of Sports Sciences in our country, activity levels of faculty students were higher than the other faculty students (6). According to a Swedish study in 2005, it was found that gender did not make a difference in determining the level of physical activity (7). Another study found that $51 \%$ of university students had inadequate physical activity (8).

In the UK, a study showed that university students tended to eat unhealthy foods that cause excessive weight and obesity to become widespread (9). In Germany, it was found that university students ate unhealthy food as a result of lack of time and lack of healthy food alternatives in canteens (10).

It may be useful to investigate the causes of changes in eating habits by qualitative research and to determine the nutritional status of the students (9). Studies in this field in our country were carried out with the students staying in the dormitory or with the students who were training at different faculties of the university such as education and medical faculties (11-18). However, no comparisons between faculties were made in any of these studies, and only comparisons between genders were reported. "Principles of Nutrition" is one of the basic courses given in most of the departments of the faculty of health sciences. The aim of this study was to evaluate the nutritional status and physical activity habits of the second, third and fourth grade students of the department of nutrition and dietetics who took this course and the second and third grade students of nursing department who did not take this course. In addition, the results of these two groups were compared.

\section{Methods}

This study was conducted in accordance with the guidelines in the Helsinki Declaration, and performing procedures involving human subjects/participants was approved by the Ethical Committee on Non-Invasive Research at Bezmialem Vakif University (No: 50222451-050.05.04-9/89). Participants were informed about the purpose of the research and informed consent was taken from participants.

The questionnaire used in the study was modified from the study of Gunes-Bayir et al. in 2015 (19). Filling out the questionnaire was done face-to-face with the participants and using visual materials (my plate food replicas; Nasco, Wisconsin; USA). The questionnaire was applied to students of the (experimental group) who took "Department of Nutrition and Dietetics (DND)" course and to students of the departmet of nursing (DN) (control group) who did not take this course in Bezmialem Vakif University Faculty of Health Sciences (İstanbul, Turkey).

In the first part of the questionnaire, socio-demographic data of the students were taken. In the second part of the study, anthropometric measurements of the students including height which was measured with wall-mount measuring tape (ADE; Tarti medical, İstanbul, Turkey), weight which was measured with bioelectric impedance analyzer (Tanita MC 780; Tarti medical, İstanbul, Turkey) and waist circumference which was measured with tape were recorded. BMI values were calculated by weight $(\mathrm{kg}) /$ height $\left(\mathrm{m}^{2}\right)$ formula and classified according to the WHO's BMI standards (20). In this classification, those less than $18.5 \mathrm{~kg} / \mathrm{m}^{2}$ were accepted as weak, those between $18.5-24.9 \mathrm{~kg} / \mathrm{m}^{2}$ were normal weight, those between $25-29 \mathrm{~kg} /$ $\mathrm{m}^{2}$ were overweight and those $30.0-34.9 \mathrm{~kg} / \mathrm{m}^{2}$ were accepted as obese. In the third part of the survey, questions about eating habits such as main dishes and snacks, the frequency of eating outside, daily water consumption, smoking and alcohol habits, etc. Were asked. In the fourth part, there were 24-hour recall with food consumption and food consumption frequency and quantity scales (2). The fifth part included questions that would determine the physical activity status of the students.

\section{Statistical Analysis}

Data obtained from the frequency and quantity of food consumption and the 24-hour recall with food consumption scales were analyzed using the Nutrition Data System (BeBIS; Pacific Electricity, Electronics and Environmental Technology Products Industry and Commerce Ltd., Istanbul, Turkey). Statistical analyses of the data were performed using SPSS 16.0 software program. Qualitative data were calculated with mean and standard deviation. The student-t test was used to compare the groups. Results were considered statistically significant when $\mathrm{p}$ value was equal to or lower than 0.05 .

\section{Results}

About half of the students $(n=171)$ in the Bezmialem Vakıf University, Faculty of Health Sciences participated in the study $(49.5 \% ; n=119)$. Forty-eight of these students were from and 71 were from. Of the students, $89.9 \%$ were under 22 years of age (mean $21.2 \pm 1.1$ years). The mean height of the students from the DN was $161 \mathrm{~cm}(148-174 \mathrm{~cm})$ and the mean height of the students from the DND was $164 \mathrm{~cm}(151-183 \mathrm{~cm})$. Also, the number of overweight $\left(\mathrm{BMI}>25-29.9 \mathrm{~kg} / \mathrm{m}^{2}\right)$ students was higher in the DN (14.5\%; $n=7)$ than in the DND $(5.6 \% ; n=4)$. Of the students from the DN, 66.6\% ( $n=32)$ were determined as being normal weight, whereas $77.4 \%$ of students from the DND $(\mathrm{n}=55)$ were determined as being normal weight $(\mathrm{p}<0.001)$. Of the students from the DN, 6.25\% ( $n=3)$ were determined as being obese, whereas $2.81 \%$ of students from the DND $(n=2)$ were determined as being obese (Figure 1).

Waist circumference measured with tape was more than $88 \mathrm{~cm}$ in $15 \%(n=7)$ of the students from the DN and in $13 \%(n=9)$ of the students from the DND.

In this study, it was found that $45.8 \%(n=22)$ of the students from the DN skipped breakfast and that the $15.4 \%(n=11)$ of the students from the DND skipped breakfast. It was found that $72.9 \%(n=35)$ of the students from the DN ate meal outside one or more in a week, whereas $63.3 \%(n=45)$ of the students from the DND ate meal outside one or more in a week. The 
percentage of skipping snacks was $12.5 \%(\mathrm{n}=6)$ in the students from the $\mathrm{DN}$ and $7 \%(\mathrm{n}=5)$ in the students from the DND. Lack of time was the most important cause of skipping meals in $54 \%(n=26)$ of the students from the DN and $43 \%(n=31)$ of the students from the DND.

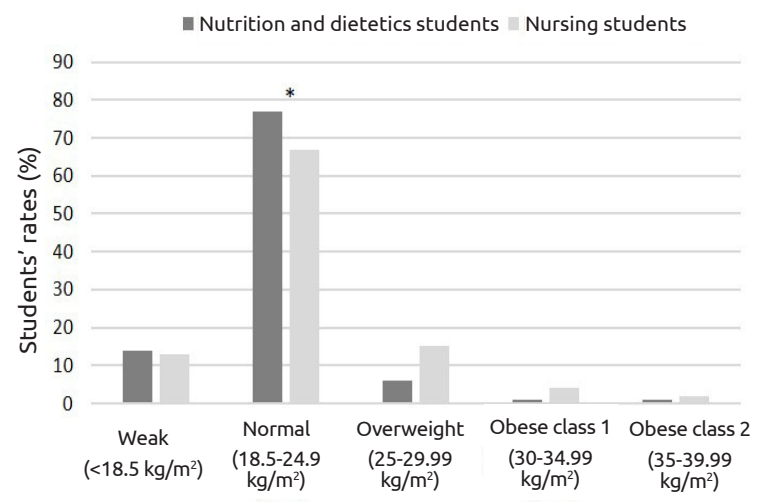

Figure 1. *Differences between control group and experimental groups statistically significant $(p<0,001)$.

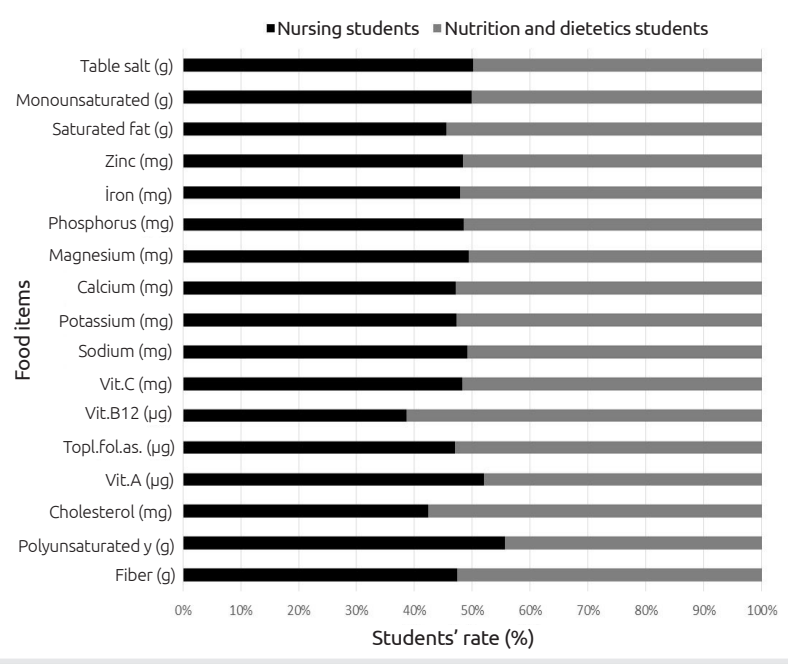

Figure 2. Comparison of nutrition consumption of the students $(n=119)$

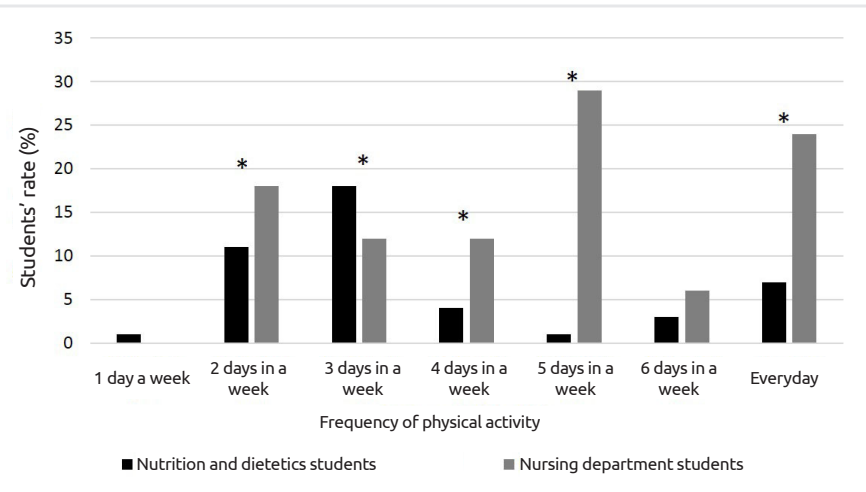

Figure 3. *Differences between control group and experimental groups statistically significant $(p<0,001)$.
The mean water consumption was $1400 \mathrm{~mL} /$ day in the students from the $\mathrm{DN}$ and was $1520 \mathrm{~mL} /$ day in the students from the DND and they were very close to each other. In addition, they reported that $10.5 \%(\mathrm{n}=5)$ of the students from the $\mathrm{DN}$ and $18.4 \%(n=13)$ of the students from the DND added salt without tasting their meals.

The total energy and nutrient intake of all students were insufficient and there was no statistically significant difference between the two groups (Figure 2). Total energy intake was $1459.2 \mathrm{kcal} /$ day with a distribution of $17.4 \%$ protein, $39.1 \%$ fat, $42.6 \%$ carbohydrate in the students from the DN, while it was $1462.2 \mathrm{kcal} /$ day with a distribution of $17 \%$ protein, $41 \%$ fat and $42 \%$ carbohydrate in the students from the DND. Fiber consumption was $15.9 \mathrm{~g} /$ day in the students from the DN, whereas it was $17.7 \mathrm{~g} /$ day in the students from the DND. In addition, mean vitamin B12 consumption was $4.10 \mu \mathrm{g}$ in the students from the DN and on it was $2.59 \mu \mathrm{g}$ in the students from the DN.

The frequency and quantity of food consumption of the groups in the study differ from each other (Table 1 and 2). Of the students from the $\mathrm{DN}, 8.3 \%(\mathrm{n}=4)$ and $18.3 \%$ of the students from the DND ( $\mathrm{n}=13)$ consumed eggs every day. The consumption of solid fat in the students from the DN was statistically significantly higher $(60.5 \% ; \mathrm{n}=29)$ than in the students from the DND $(\mathrm{p}<0.001)$.

It was found that $55 \%(n=55)$ of the students from the DND and $35 \%(n=17)$ of the students from the DN were physically active and that this activity was achieved by walking in 34\% $(n=24)$ of the students from the DND and $31 \%(n=15)$ of the students from the DN (Figure 3; $\mathrm{p}<0.001$ ).

\section{Discussion}

One hundred and ninety students, aged between 19 and 25 years, participated voluntarily in this study. Of the students participated in this study, $84.8 \%(\mathrm{n}=101)$ reported that they consumed milk and milk products every day. According to a study conducted at Gaziosmanpaşa University, only $28.67 \%$ of the students consumed milk on a regular basis and $33.33 \%$ consumed milk products on a regular basis (11). However, this result was not supported by our work.

In a study conducted by Ozdogan et al. (12), 89.5\% of the students skipped their main meals and the most skipped main meal was breakfast. According to a study conducted in 2010 at Uludağ University, the most skipped meal was breakfast (24.8\%) and $90 \%$ of the students paid attention to the consumption of snacks (13). In our study, $88.2 \%$ of the students skipped meals and the most skipped meal was found to be breakfast (31.4\%). It was observed that $90.7 \%$ of the students pay attention to eating snacks. With these findings, it can be said that the students in our research group exhibited the same nutritional behavior as the students in the Uludag University. 
Table 1. The frequency of nutrition consumption of the students from the Department of Nutrition and Dietetics $(n=71)$

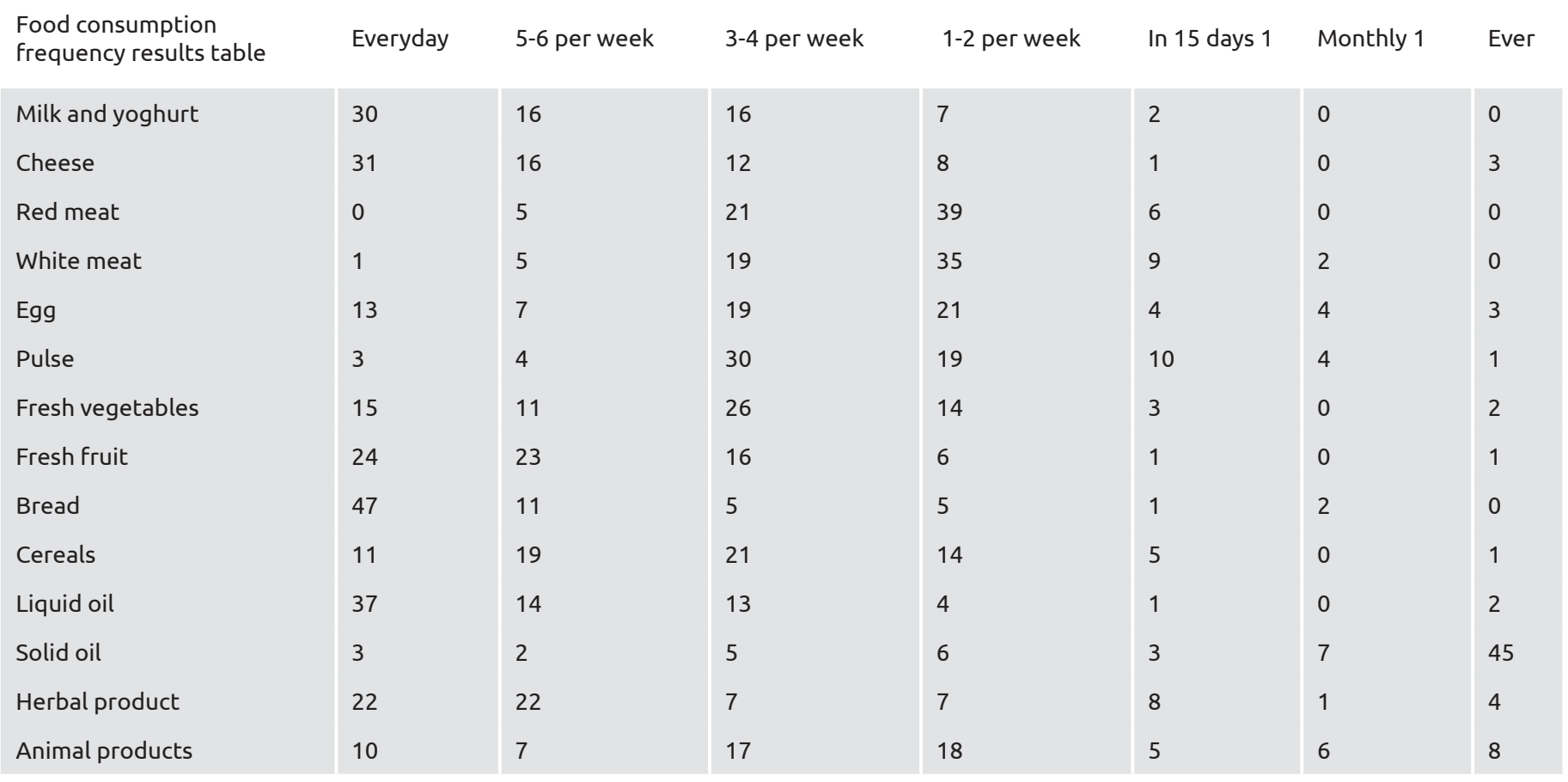

Table 2. The frequency of nutrition consumption of the students from the department of nursing $(n=48)$

\begin{tabular}{|c|c|c|c|c|c|c|c|}
\hline $\begin{array}{l}\text { Food consumption } \\
\text { frequency results table }\end{array}$ & Everyday & 5-6 per week & 3-4 per week & 1-2 per week & In 15 days 1 & Monthly 1 & Ever \\
\hline Milk and yoghurt & 20 & 9 & 8 & 8 & 2 & 0 & 1 \\
\hline Cheese & 20 & 10 & 11 & 5 & 0 & 0 & 2 \\
\hline Red meat & 1 & 3 & 5 & 18 & 6 & 11 & 4 \\
\hline White meat & 0 & 4 & 16 & 17 & 8 & 3 & 0 \\
\hline Egg & 4 & 5 & 10 & 21 & 3 & 2 & 3 \\
\hline Pulse & 1 & 2 & 19 & 17 & 8 & 1 & 0 \\
\hline Fresh vegetables & 8 & 9 & 15 & 13 & 1 & 2 & 0 \\
\hline Fresh fruit & 10 & 12 & 13 & 10 & 2 & 0 & 1 \\
\hline Bread & 35 & 3 & 2 & 3 & 0 & 1 & 4 \\
\hline Cereals & 3 & 8 & 16 & 16 & 2 & 0 & 3 \\
\hline Liquid oil & 24 & 2 & 9 & 3 & 0 & 1 & 9 \\
\hline Solid oil & 5 & 2 & 5 & 10 & 1 & 6 & 19 \\
\hline Herbal product & 11 & 4 & 10 & 10 & 2 & 8 & 3 \\
\hline Animal products & 8 & 2 & 3 & 16 & 1 & 2 & 16 \\
\hline
\end{tabular}

In a study conducted at Erciyes University, $48.9 \%$ of the students ate three meals a day $(14,15)$, while $46.5 \%$ of the students ate two meals a day and $44.5 \%$ ate three meals a day in a study conducted at Erciyes University (16). In our study, it was found that $47.8 \%$ of the students ate three meals, while $16.8 \%$ ate four meals.
The reasons for skipping meals of the students were investigated by Memis (17). in a study and it was noted that lack of time was the most common reason for skipping meal in $62.7 \%$ of the students. In our study, lack of time was the most common reason for skipping meal with a rate of $47.8 \%$. 
Gülec et al. (18) showed that most preferred food was fruits and vegetables in the main meals at a rate of $25.3 \%$ in the students. In our study, it was found that milk and milk products were the most preferred food at a rate of $32.7 \%$ in the main meals.

Of the students who participated in our study, 89\% said "No" to the question of "Have you used cigarettes in the past?". A study at Uludağ University Faculty of Medicine concluded that $82.7 \%$ of the students did not smoke (21). According to a study conducted in different faculties at Uludağ University, the rate of non-smoking students was $63.6 \%$ (13). Based on these results, we can conclude that the smoking rate of the students in health departments is lower.

In our study, $10 \%$ of the students from both departments $(n=12)$ had physical activity for 5 days per week and $15.9 \%$ of them $(\mathrm{n}=19)$ had activity time for 30 minutes. A study in Florida found that $86.6 \%$ of the students had regular physical activity for at least five days a week and 30 minutes per day (22).

\section{Conclusion}

As a result, it was found that the students from the DND had more healthy eating habits compared to the students from the $\mathrm{DN}$, but the students from both departments were malnourished. In addition, higher BMI results were obtained in the DN compared to the DND and therefore the number of students in the risky group was found to be higher. It was found that the physical activity level of the students was higher in the DND. A significant difference between the students from the DND who took the "Nutrition Principles" and the students from the DN who did not take the course in terms of consumption of various food groups which are beneficial/harmful to health, emphasized the importance of this course in education.

\section{Ethics}

Ethics Committee Approval: This study was conducted in accordance with the guidelines in the Helsinki Declaration, and performing procedures involving human subjects/participants was approved by the Ethical Committee on Non-Invasive Research at XXX University (No: 50222451-050.05.04-9/89).

Informed Consent: Participants were informed about the purpose of the research and informed consent was taken from participants.

Peer Review: Externally peer-reviewed.

\section{Authorship Contributions}

Concept: A.G.B., Design: A.G.B., Data Collection or Processing: D.G., A.G.B., Analysis or Interpretation: A.G.B., D.G., Literature Search: D.G., Writing: A.G.B., D.G.

Conflict of Interest: No conflict of interest was declared by the authors.

Financial Disclosure: The authors declared that this study received no financial support.

\section{References}

1. Brook Robert H. Should the Definition of Health Include a Measure of Tolerance? JAMA 2017;317:585-6.

2. Pekcan G. Beslenme durumunun saptanmasi. Diyet El Kitabi. Hatipoğlu Yayınevi. Ankara, 2008;67-141.

3. Dyson R, Renk K. Freshmen adaptation to university life: Depressive symptoms, stress, and coping. J Clin Psychol 2006;62:1231-44.

4. Ferrara C, Nobrega C, Dulfan F. Obesity, diet, and physical activity behaviors of students in health-related professions. Coll Stud J 2013;47:560-5.

5. Aslan UB, Livanelioğlu A, Aslan Ş. Fiziksel aktivite düzeyinin üniversite öğrencilerinde iki farklı yöntemle değerlendirilmesi. TJPR 2007;18:11-9.

6. Şahin M, Kırandı Ö, Atabaş G, Bayraktar B. Spor Bilimleri Fakültesi Öğrencilerinin Fiziksel Aktivite Düzeyleri (İstanbul Üniversitesi Örneği). Spor Eğitim Derg 2017;1:26-33.

7. Von Bothmer MIK, Fridlund B. Gender differences in health habits and in motivation for a healthy lifestyle among Swedish university students. Nurs Health Sci 2005;7:107-18.

8. Martin SB, Morrow JR, Jackson AW, Dunn AL. Variables related to meeting the CDC/ACSM physical activity guidelines. Med Sci Sports Exerc 2000;32:2087-92.

9. Waldhäusl S, Aceijas C, Lambert N, Bello-Corassa R. Determinants of nutritional imbalance among UK university students: a cross sectional study. Eur J Public Health 2016;26:174.

10. Hilger J, Loerbroks A, Diehl K. Eating behaviour of university students in Germany: Dietary intake, barriers to healthy eating and changes in eating behaviour since the time of matriculation. Appetite 2017;109:100-7.

11. Uzunöz $M$, Gülşen $M$. Üniversite öğrencilerinin süt ve süt ürünleri tüketim alışkanlıklarının belirlenmesi. Gıda Teknolojileri Elektronik Dergisi 2007;3:15-21.

12. Özdoğan Y, Yardımcı H, Özçelik A, Sürücüoğlu MS. Üniversite öğrencilerinin öğün düzenleri. Gazi Üniv ESEF Derg 2012;29:66-74.

13. Korkmaz NH. Uludağ Üniversitesi öğrencilerinin spor yapma ve beslenme alışkanlıklarının incelenmesi. Uludağ Üniv Eğ Fak Derg 2010;23:399-413.

14. Bayrak U, Gram E, Mengeş E, Okumuş ZG, Sayar HC, Skrijelj E, et al. Üniversite öğrencilerinin sağlıkla ilgili alışkanlıklar ve kanser konusundaki bilgi ve tutumları. DEÜ Med J 2010;24:95-104.

15. Mazıcıŏlu M, Öztürk A. Üniversite 3.ve 4.Sınıf Öğrencilerinde Beslenme Alışkanlıkları ve Bunu Etkileyen Faktörler. Erciyes Med J 2003;25:172-88.

16. Sağlam F, Yürükçü S. Ankara Üniversitesi Eğitim Bilimleri Fakültesi Yüksek Okul Örgencilerinin Besin Tüketim Durumu, Beslenme Alışkanlıkları ve Beslenme Bilgi Düzeylerinin Saptanması. Besl Diyet Derg 1996;25:16-23.

17. Memiş E. Üniversite öğrencilerinde şişmanlık (obezite) durumu ve diyet ürünleri kullanmaları üzerinde bir araştırma. Yayımlanmamış 
Yüksek Lisans Tezi, Gazi Üniversitesi Eğitim Bilimleri Enstitüsü, 2004.

18. Güleç M, Yabancı N, Göçgeldi E, Bakır B. Ankara'da iki kız öğrenci yurdunda kalan öğrencilerin beslenme alışkanlıkları. Gulhane Med J 2008;50:102-09.

19. Gunes-Bayir A, Kiziltan HS, Sentürk N, Mayadaglı A, Gumus M. A Pilot Study of Self-Reported Physical Activity and Eating Habits in Turkish Cancer Patients Under Chemotherapy. Nutr Cancer 2015;67:906-11.
20. Kabiru W, Raynor BD. Obstetric outcomes associated with increase in BMI category during pregnancy. Am J Obstet Gynecol 2004;191:928-32.

21. Vatan İ, Ocakoğlu H, İrgil E. Uludağ Üniversitesi Tıp Fakültesi Öğrencilerinde Sigara İçme Durumunun Değerlendirilmesi. TAF Prev Med Bull 2009;8:43-8.

22. Downes L. Physical activity and dietary habits of college students. J Nurse Pract 2015;11:192-8. 